\title{
A Guide for Cooperative Teachers to Enhance Vocabulary Acquisition Through The Use of Animated Television Series in the Fourth Grade at a Primary School
}

Jairo A. Hoyos

Universidad Surcolombiana, Colombia jairohoyostheunitedkingdom@gmail.com

\section{Resumen}

Se extrajo vocabulario de algunos episodios de las series animadas de televisión Peppa Pig y Horrid Henry, con el objetivo de diseñar una guía docente para profesores cooperadores. Esto es debido a que se manifiesta una gran brecha que los practicantes dejan cuando terminan su proceso de práctica docente hasta que llega un nuevo practicante. Los estudiantes no solo aprendieron vocabulario sino que fortalecieron todas las habilidades lingüísticas. La metodología implementada fue investigación-acción. Con respecto a los resultados; Las encuestas, las observaciones, los diarios, los ejercicios y las notas finales se evidenció que enseñar vocabulario a través del uso de series de televisión animadas impactó e incrementó la motivación de los estudiantes y la interacción de la clase. No solo la motivación de los estudiantes se vio influida, sino que los resultados de sus exámenes aseguraron la eficacia de trabajar con caricaturas animadas para aprender vocabulario en el aula. En conclusión, el uso de este tipo de material autentico en la clase de inglés genera un gran impacto en la enseñanza y aprendizaje de cada estudiante como también mejora la adquisición de vocabulario. 


\section{Introduction}

"Departamental Tierra de Promision - El Lago" primary school was highly involved and committed in the implementation of the innovation project. There are six primary school teachers who are in charge of educating the pupils in all subjects except for English. One of the previous student teachers who was doing his student teaching last semester at this school is being hired to teach English by the cooperative teachers during the gap of time which is left after the student teachers finish their practicum process.

The fourth graders are the participants of this pilot research. They are quite talkative when their English teacher assigns them to do some activities. Even though, when the cooperative teacher notices that the students are misbehaving and mistreating the English teacher, she tells them off and that is the moment when the children stay quiet. It was remarkably perceived that there are two girls who tend to sabotage the lesson. The schoolchildren are really intelligent because most of the time when they participate, they do it quite well and sometimes work on their exercises thoughtfully.

I extracted some vocabulary from some animated television series called Peppa Pig and Horrid Henry to design a teacher's guide for the cooperative teachers because there is a huge gap that student teachers leave after finishing their practicum process until a new student teacher arrives. It took about six sessions and some extra hours working for the preparation of the teacher's guide. There is a huge variety of games and activities to reinforce their vocabulary acquisition during the procedure of implementing this research. Not only to learn vocabulary but to foster all the language skills as well. There will be some listening, writing, speaking and reading exercises to acquire a whole and integrated knowledge of a specific topic regarding vocabulary.

Concerning the results of this pilot study; the surveys, the observations, the journals and the academic results from the exams and the exercises showed how this research impacted the students and increased impressively their motivation and the interaction of the lesson. They were encouraged to learn vocabulary through the use of animated television series. It cultivated the use of healthy competition to learn English. The students were really happy and motivated to keep watching this kind of episodes to learn vocabulary.

\section{Diagnosis}

To find more accurate and compelling data to state the problem, I conducted some observations, some surveys for the students and some interviews for the cooperative teachers before the student teaching took place. Triangulating the information gathered would help to see plainly what the downsides are. As there is so much data, the most relevant information will be given in a brief summary.

First, there was a question in the survey for the students regarding what they did not like about their English lesson. 53, 33 percent of the students claimed that the lesson was 'boring' and they 'did not like writing' on their notebooks. 13, 33 percent of them said that the teacher 'did not bring games'. I could identify in the observation that there was a lot of signs or evidence that would determine why the children were likely to get bored. There are thirty two students from the fourth grade in one room.

They are undisciplined. There was no motivation for the students to work in teams. As there is no professional English teacher, they were taught vocabulary through the traditional method which is writing the word and drawing it on the board. Regarding the interviews, one of the cooperative teachers said that there was indiscipline among the students, they felt afraid to talk openly and they did not pay attention. Another teacher said she did not like the fact that there was no material to teach English. It is quite convincing the fact that the students easily get bored because they were taught the wrong way. They were not inspired to work in pairs or teams. The teacher is the one responsible for this issue because if trained teachers gave a lesson, they would do their best to bring innovation to their classrooms, their 
students would get excited and each lesson would be an adventure for the pupils.

Second, there was another question related to what kind of activities the students wanted to have in the lesson. 86, 66 percent of the students affirmed they wanted the new teacher to bring material to learn English such as 'animated television series', films and videos. Concerning the observation, the teacher did not use any games, flashcards or ice-breakers to start the lesson. There was no use of the TV or the video beam. With respect to the interviews, the teachers mentioned they wanted to have the students to watch films and more videos, to listen to songs, to play games and to watch animated television series. Another one said she wanted the students to participate in contests. It is not a secret that the students are longing for innovation to their lessons. They want to have animated television series, to play games and so many different activities in their classrooms.

Third, other question from the survey was about if the school provided material to learn English through the use of animated television series. 60 percent of them stated that there was no material to learn through animated television series at the school. With reference to the observation, there was no use of didactic material to teach EFL. The teacher had to photocopy some material for the children and there was no use of animated television series either. As for the interview, all the teachers reaffirmed that there was no material to teach EFL through the use of animated television series. Due to the fact that there was no material at the school to teach English, it was really crucial to design material that got them excited and motivated.

Finally, another question from the survey was related to designing material to learn English through the use of animated television series. 93. 33 percent of the students agreed. They were also asked to give a reason for their answer. 46, 66 percent mentioned that they could learn more English and vocabulary. In regard to the observation, the students did not have a textbook that guided them to learn English nor did the teachers have a teacher's guide to teach English. In relation to the interviews, the teachers said they needed to have some material to teach easily to the children. One teacher remarked that they needed someone professional to teach English because they do not know vocabulary and how to pronounce the words. Another teacher said she would be willing to help with extra hours if she had some material to teach English. To sum up the last statement, one of the teachers claimed that she would be willing to teach English if she had the material. The cooperative teachers could be trained and a practical guide could be designed for them with some audio recordings to help with the pronunciation so that they could teach English to their students avoiding hiring someone else.

\section{Objectives}

\section{General Objective}

- Determine the impact of the use of the animated television series to teach vocabulary in the fourth grade at Departamental "Tierra de Promision El Lago" Primary School

\section{Specific Objectives}

- Describe the impact that the animated television series may have on the students' motivation in the English lesson.

- Identify if the tasks or exercises designed to work with the animated television series contribute meaningfully to the vocabulary acquisition.

\section{Literature Review}

\section{Vocabulary Acquisition}

According to Nakata, learning vocabulary requires a persistent repetition to achieve success in vocabulary acquisition (p.19). It cannot be compared to grammar as it has a different function in the language. Discipline in learning vocabulary is very crucial to acquire and remember a high frequency of new words. Putting the new words in the long term memory is an essential function of the brain which is a key factor for the learner to take into account. This is the whole essence of 
acquisition. Nation and Waring (1997) claimed that learners must have a permanent contact with new words different amount of times in the authentic context (p.6).

\section{Authentic materials}

Authentic Materials have a pretty different purpose rather than teaching and learning a new language. However, this type of materials provides a real use of the language which might be of great help to contribute meaningfully to the new learner. They are mostly found in print and audio. They could be magazines, newspapers, reports cards, phone messages, radio broadcasts, movies, and podcasts and so on. (Ianiro, S., 2007, p.1).

\section{Teaching English through Animated Cartoons}

Bankole Faloye (2013) carried out a study in which he tried to find out the effectiveness of using animated cartoons in teaching English grammar with particular emphasis on vocabulary development at St Louis Nursery and a primary school in Nigeria. He set aside two groups in which an experimental design was used. One group was selected to learn through the Grammar translation Method and the other was aimed to learn aspects of English grammar through animated cartoons during interactive sessions to compare the effectiveness of cartoons in the classroom. The former was called the control group and the latter the experimental group. The classroom material for the experimental group was based on the animated cartoon "Word Girl" while the other group learned through the traditional approach to grammar which is stipulated by the Ministry of Education. The findings showed that children learn new words faster and foster their vocabulary development through animated cartoons. The keen interest of the students in the experimental group in the use of animated cartoons was noticeable. There was a meaningful difference between the scholars who were taught with the aid of animated cartoons and those who were taught without them using their post-test scores. They did not want to leave the classroom even after each lesson ended.

\section{Methodology}

\section{Action Research}

People who are involved in the research community are the participants in this self-reflective, systematic and critical approach. The principal objective is to find any downfall in the current field of implementing the project which is worthy to investigate to convey critical well-informed data. The ownership of change is highlighted during the whole process of the investigation which is a democratic ideal for Action Research. (Burns, A., \& Cornwell, 2010, p. 5)

Kemmis and McTaggart (1988) are the ones who master this qualitative method and explain that AC consists of four broad stages of the cycle of research that may come to be repetitive and a spiral of cycles. This continuing process of improvement may stop until the objectives are achieved. The four broad stages are planning, action, observation and reflection.

1. Planning: the researcher needs to identify what the pitfalls are to come up with a plan of action in a specific area to carry betterment to the research context. This is a forward-looking phase where you consider: i) what kind of investigation it is possible within the realities and constraints of your teaching situation; and ii) what potential improvements you think that are possible.

2. Action: the plan of action which is the proposal needs to be developed into different interventions so that the researcher can put into action what he/she has planned in a certain period of time. The interventions are 'critically informed' about the current situation.

3. Observation: This is the moment for the researcher to start observing and documenting the reaction of the participants which involves comments, actions, interviews etc. It is a data collection phase where the researcher uses 'open-eyed' and 'open-minded' tools to collect information about what is happening.

4. Reflection: the researcher should reflect, describe, analyze and evaluate all the data collected from the research instruments to plainly 
comprehend what has happened. The researcher may decide to do further cycles of AR to improve the situation even more, or to share the 'story' with others as part of his or her ongoing professional development (p. 11-14).

Research Instruments: surveys, observations and journals.

\section{Programming}

Table 1. A brief description of the content of

\begin{tabular}{|c|c|c|}
\hline No & Intervention title & Strategy Description \\
\hline 1 & $\begin{array}{l}\text { Hammer Battles } \\
\text { (Listening \& Speaking) } \\
\text { PRE-TEACHING } \\
\text { Vocabulary Challenge } \\
\text { (Listening \& Reading) }\end{array}$ & $\begin{array}{l}\text { Hammer Battles: After reviewing } \\
\text { the vocabulary items on flashcards, } \\
\text { the students show what they have } \\
\text { remembered by locating the correct } \\
\text { flashcard and hitting it with a plastic } \\
\text { hammer. The teacher says the word and } \\
\text { a student will locate the picture card. } \\
\text { Then, a student chosen by the teacher } \\
\text { does his job of saying the word for the } \\
\text { team member to hit the picture word. } \\
\text { Vocabulary Challenge: The teacher } \\
\text { plays a song and then stops it. After that, } \\
\text { the teacher says a word. The students } \\
\text { have some time to point to the word card } \\
\text { and the picture. Finally the teacher plays } \\
\text { the song again. The student who points } \\
\text { the wrong word card and picture is "out". } \\
\text { Until one child remains. }\end{array}$ \\
\hline 2 & $\begin{array}{l}\text { Memory Game (Reading ) } \\
\text { (Listening \& Speaking) } \\
\text { PRE-TEACHING } \\
\text { Watch the Animated } \\
\text { Television Series (Listening) }\end{array}$ & $\begin{array}{l}\text { Memory Game: A team member has to } \\
\text { find picture / word combinations. If he or } \\
\text { she does find it, their team will win coins } \\
\text { to stick on the Score Board. } \\
\text { * Students draw each word and write the } \\
\text { name of it to create their own dictionary. } \\
\text { * The students watch three episodes of the } \\
\text { animated television series called Peppa } \\
\text { Pig to do their first listening exercise (The } \\
\text { Golden Fish Episode, Lunch Episode \& } \\
\text { Picnic Episode) }\end{array}$ \\
\hline 3 & $\begin{array}{l}\text { Watch the Animated } \\
\text { Television series (Listening) } \\
\text { WHILE-TEACHING } \\
\text { Writing Exercise }\end{array}$ & $\begin{array}{l}\text { The students watch and listen to the } \\
\text { animated television series called Peppa } \\
\text { Pig and at the same time do some listening } \\
\text { exercises. (Shopping Episode \& Fruit Day } \\
\text { Episode) } \\
\text { Writing Exercise: Students have to } \\
\text { write some sentences in the dictionary } \\
\text { bellow each word using the vocabulary } \\
\text { learnt. }\end{array}$ \\
\hline
\end{tabular}




\begin{tabular}{|c|c|c|}
\hline 4 & $\begin{array}{l}\text { Watch the Animated } \\
\text { Television series (Listening) } \\
\text { Speaking Exercise } \\
\text { WHILE-TEACHING }\end{array}$ & $\begin{array}{l}\text { The students watch and listen to the } \\
\text { animated cartoons called Horrid Henry } \\
\text { and at the same time do some listening } \\
\text { exercises. (Horrid Henry's Perfect Day) } \\
\text { Speaking Exercise: Students have to say } \\
\text { whether they like or not some food when } \\
\text { the teacher shows the flashcard. }\end{array}$ \\
\hline 5 & $\begin{array}{l}\text { Vocabulary Chart } \\
\text { Written Exam (listening, } \\
\text { speaking, reading \& writing) } \\
\text { (2 lessons) } \\
\text { POST-TEACHING }\end{array}$ & $\begin{array}{l}\text { Vocabulary Chart: Children revise the } \\
\text { vocabulary by finding words that starts } \\
\text { with a given letter. They work in teams. } \\
\text { Teams must race to find a word for each } \\
\text { letter. The first team to have a word for } \\
\text { each letter wins. } \\
\text { * The students have to choose an episode } \\
\text { previously watched for their listening test. } \\
\text { *The teacher asks some questions related } \\
\text { to their likes and dislikes and the students } \\
\text { have to answer them. } \\
\text { *The students have to write the name of } \\
\text { the word below each picture and describe } \\
\text { whether they like it or not. } \\
\text { * Students have to read and fill the gaps. }\end{array}$ \\
\hline & $\begin{array}{l}\text { Rehearsal and preparation for } \\
\text { the decoration of the final } \\
\text { session }\end{array}$ & $\begin{array}{l}\text { Before the event takes place, the teacher } \\
\text { has to work with the students in order } \\
\text { to draw and paint on cardboards and } \\
\text { paper all the vocabulary learned and } \\
\text { the characters of the animated television } \\
\text { series for decorating the room where the } \\
\text { final session is going to be set up. The } \\
\text { students will have to create their costumes } \\
\text { using different kind of materials and wear } \\
\text { them that day. In addition to that, the } \\
\text { teacher will teach a very simple script to } \\
\text { each team to perform a sketch. There will } \\
\text { be a family pig in each group like Peppa } \\
\text { Pig. They will have to develop their acting } \\
\text { skills too. They will do some rehearsal to } \\
\text { sing the chants for the chant contest. }\end{array}$ \\
\hline
\end{tabular}




\begin{tabular}{|c|c|c|}
\hline 6 & $\begin{array}{l}\text { Event (Final Test; Speaking) } \\
\text { Horrid Henry's Fun Fest } \\
\text { POST-TEACHING }\end{array}$ & $\begin{array}{l}\text { This session will show what they have } \\
\text { been learning during the whole process of } \\
\text { this project. There will be some time to } \\
\text { display their dictionaries like it occurs at } \\
\text { an art gallery. Everything mentioned will } \\
\text { be the evaluated by the teacher and the } \\
\text { juries. } \\
\text { Timetable } \\
\text { 1. A video from the project } \\
\text { 2. An episode from Peppa Pig } \\
\text { 3. The Juries' presentation. } \\
\text { 4. Chant Contest: Lions, Tigers \& Sharks } \\
\text { (Teams) } \\
\text { 5. One Minute Vocabulary Challenge } \\
\text { contest } \\
\text { 6. Gallery (Dictionaries, posters and food } \\
\text { presentation) } \\
\text { 7. Five Minute Play Contest (Sketch) } \\
\text { 8. An episode from Peppa } \\
\text { 9. Prizes } \\
\text { 10. Photo session }\end{array}$ \\
\hline
\end{tabular}

\section{Findings}

The following results were obtained using surveys, journals and observations. The surveys were designed for the participants, the observations were reported in a form by some people involved in this education field and the journals were written by the student teacher. To analyse the outcomes, it is quite crucial to triangulate the data. As there is too much information, only some key aspects will be mentioned.

First, one of the questions that were put to the observers was related to what the impact of teaching vocabulary through the use of animated television series to the fourth graders was. They reported that the impact was high because this kind of animated television series catches the attention of any kid at that age, every word used in these episodes are easy to understand and the words are commonly used in their own language. Regarding the survey, 54, 16 percent of the students stated that the animated television series were interesting and 62,5 percent of them reaffirmed that the animated television series provided the opportunity to learn, understand and pronounce new words in a meaningful context. With reference to the journals, the students' attention was higher while they were watching the episode and their behaviour was even better than in all the transitions of the class. Their eyes were fully focused on the episodes as well. It could be reported through these findings that the students have been greatly impacted through the use of animated television series; they like these episodes and are encouraged to learn vocabulary.

Second, another question which was asked to the observers was about describing the students' motivation and the interaction of the lesson. They mentioned that the students were happy, attentive and motivated to the teaching. The interaction was good and every method catches the students' attention effectively. The survey proclaimed that 41, 66 percent of the students felt motivated to use animated television series to learn vocabulary. It was described in the journals that there was too much interaction in participation in the lessons. The lessons were astonishing because all of the 
students wanted to give a hand to the student teacher in everything he needed. They were filled with so much motivation that the student teacher had to use some strategies to monitor their excess of motivation. He used the Score Board and a Treasure Chest. As the students had to work in teams during the whole application of the project, they were warned. If they overreacted or misbehaved, they could lose points from their Score Board.

Third, another question for the observers was about discovering whether the students have learnt or not during this project. They reported that the students showed their background knowledge during the last session and that the students did not have a wide range of vocabulary before the project was going to be implemented. As for the survey, 62, 5 percent of the students verified that they can identify the words learnt when listening to an animated television series (listening skill). 62, 5 percent of them evidenced they can understand the words learnt in a written text (reading skill). 70, 83 percent of the students confirmed that the different activities helped them to use the words learnt to describe their likes or dislikes orally (speaking skill). 50 percent of them said that they can use the words learnt to write questions and answers (writing skill). As to the journals; during the last session, the students showed what they have learnt during the whole implementation of the project. The students could remember the script of the sketch quite well. They sang as never before. They showed their dictionaries done in the previous lessons. One of the students had to say the name of all the food learnt in front of the audience and she did a great job. The students have shown that they have learnt a lot during the whole process through the different exercises and exams (speaking test, writing test, reading test and listening test). The average result of their final score was above 4.0.

Finally, another question for the observers was related to say whether the material used (Peppa Pig's episodes) in the sessions is a meaningful source for the students to learn vocabulary or not. They confirmed that the animated television series are a meaningful source to learn vocabulary. The students learn easily because the episodes catch their attention. One of them said that the teacher knows how to bring impact in his teachings. As it was mentioned before, 41, 66 percent of the students reported that they felt motivated to learn vocabulary through the use of animated television series. As to the journals, the student teacher noticed that one of the students in one session could understand the dialog of the episodes of Peppa Pig because it was quite simple. He could recognise the words in the dialog.

Chart 1. This bar chart describes the preferences of the participants regarding the statements from the survey.

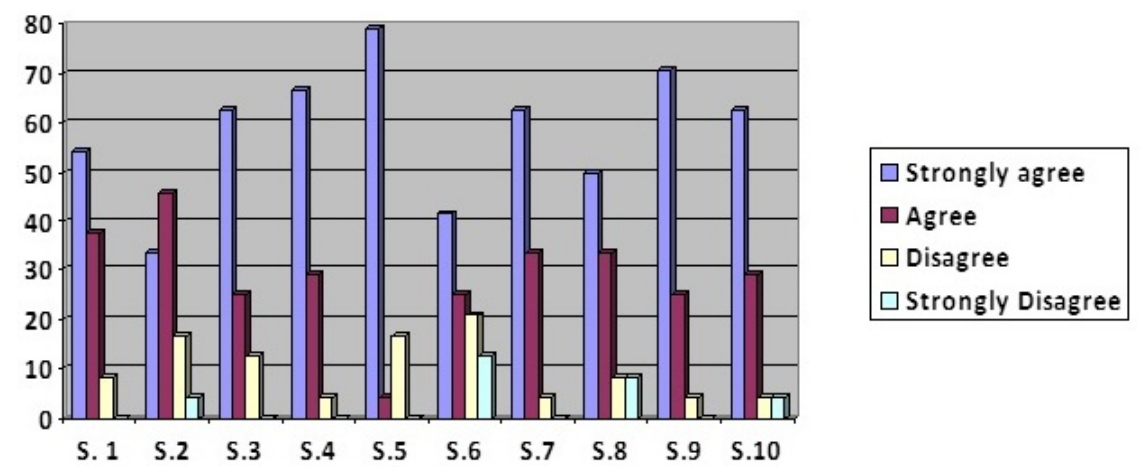

Statement 1: The episodes of the animated television series are interesting.

Statement 2: The type of tasks were challenging to me.

Statement 3: The animated television series gave me the

opportunity to learn, understand and pronounce the words learnt in a meaningful context.

Statement 4: Teamwork helped me to improve my learning process.

Statement 5: I enjoyed teamwork. 
Statement 6: I felt motivated to use animated television series to learn vocabulary.

Statement 7: I can identify the words leant through listening to animated television series.

Statement 8: I can write questions and answers using the words learnt.

Statement 9: I can describe likes and dislikes using the words learnt orally.

Statement 10: I can understand the meaning of the words learnt in a written text.

\section{Conclusions}

To come up with the conclusions, the implementation of this research study has greatly impacted the students from the fourth grade. Implementing this authentic material among children in the lesson impacts their vocabulary acquisition and enhances their motivation to learn the target language. The use of animated television series is really useful to learn vocabulary in the classroom. It is interesting to use this kind of material. It affects their behaviour in the sessions positively. Whenever they watch the episodes, they stay quiet and pay close attention to the animated television series. The motivation of the students increases along the teaching process. It can reach a high level of the interaction of the lesson that the teacher has to monitor their behaviour through the use of teamwork and the pedagogical strategies such as giving them some didactic coins that they take from the Treasure Chest to stick them on the Score Board. These strategies encourage them to work in teams. They do learn how to sing the chants through the use of teamwork. This material (the animated television series' episodes) is a really meaningful source to learn vocabulary. The students learn how to work in teams and at the same time they improve their academic performance.

\section{Recommendations}

As there is too much hard work involved during this process of implementing this project, the recommendation for the practitioners who will get involved in this pilot study is to work really hard on monitoring the students' motivation. As it was mentioned before; one of the students' pitfalls is the excess of motivation to learn English that the students acquire through every session. It is really crucial to make clear to the students the use of the Score Board and the Treasure Chest to control their behaviour during each session.

\section{References}

1. Copland, F., Garton, S., Davis, M. (2012). Crazy Animals and Other Activities for Teaching English to Young Learners. ,[PDF].teaching English, British Council, London, UK

2. Burns, A., \& Cornwell. (2010). Chapter 1. In A. Burns (Author), Doing Action Reserach in English Language Teaching (First Edition ed., Esl \& applied linguistics professional series, p. 5). New York: Taylor \& Francis Group.

3. Faloye, B. (2013). The Effect of Animated Cartoons on Teaching English Grammar: A Study of St Louis Nursery and Primary School,[PDF]. Ikere -Ekiti, Nigeria.

4. Ianiro, S. (2007) Authentic materials. Professional development Fact sheet, No (1), American institute for Research

5. Kemmis, S., McTaggart, R., (1988). Introduction: the nature of action research, In: Kemmis, S., McTaggart, R. (Eds.) (p. 11-14), The Action Research Planner, 3rd ed. Deakin University Press, Melbourne, Australia.

6. Nakata, T. (2006). Implementing optimal spaced learning for English vocabulary learning: Towards improvement of the low-first method derived from the reactivation theory. The JALT CALL Journal, 2(2), 3-18

7. Nation, P., \& Waring, R. (1997). Vocabulary size, text coverage and word lists. In N. Schmitt \& M. McCarthy (Eds.), Vocabulary: Description, acquisition and pedagogy (pp. 6-19). Cambridge, UK: Cambridge University Press. Retrieved March 3, 2006, from http://www1.harenet.ne.jp/ waring/paper s/cup.html 
Appendix A

Movie Fun Fest Event

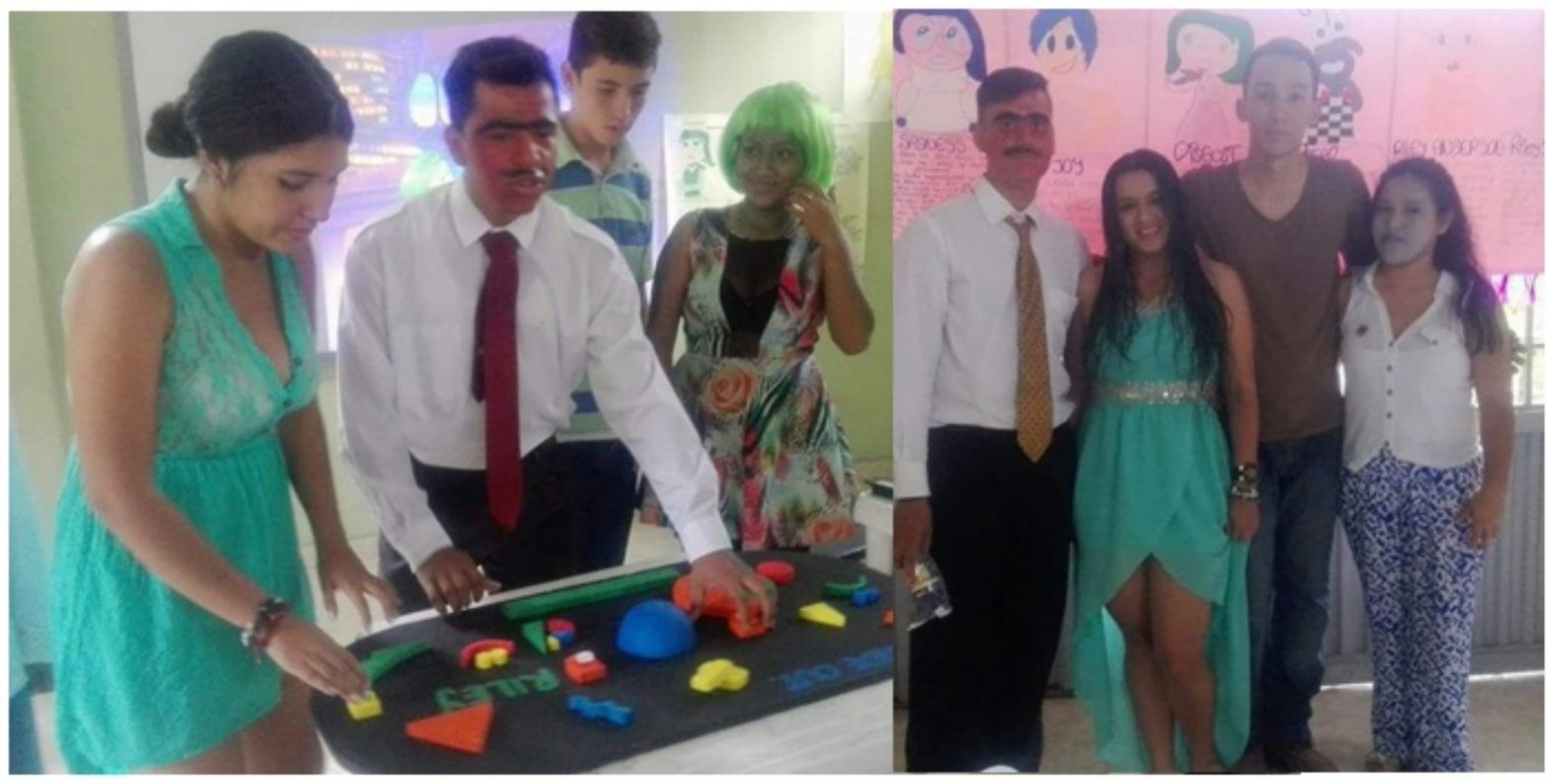

Poster Session

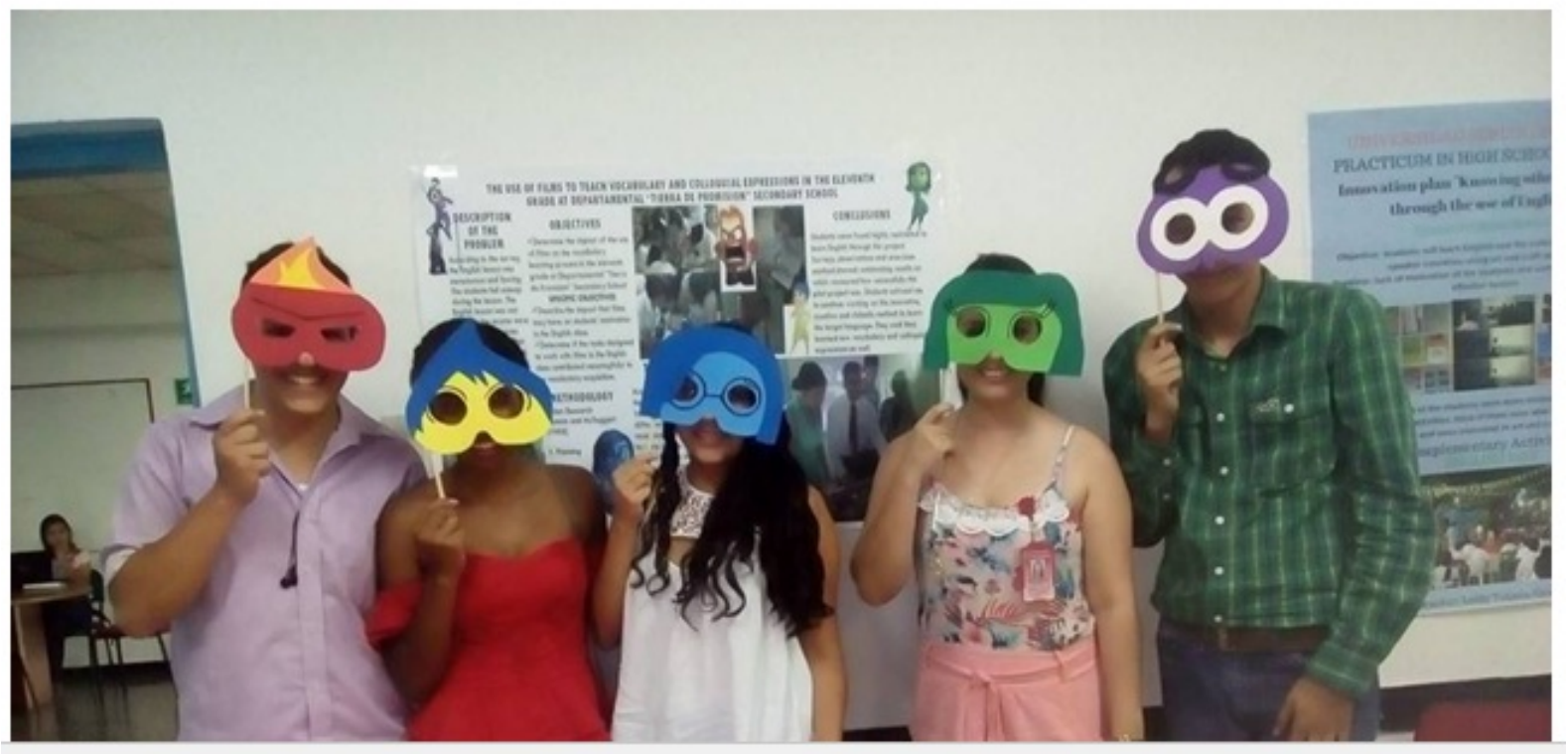

